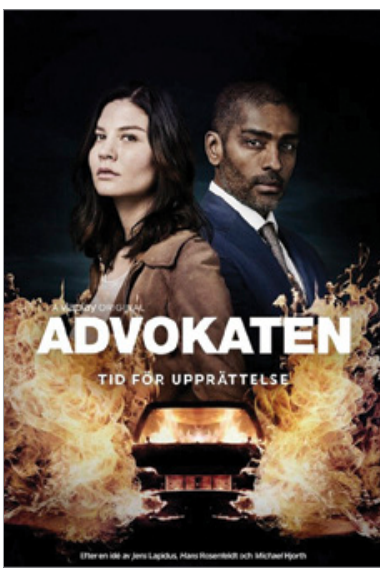

\section{ADVOKATEN}

\section{$\mathrm{Na}$ The Bridge en Bordertown is er een nieuwe Scandinavische thrillerreeks verschenen. \\ Het Zweeds-Deense Advokaten ('The Lawyer') is nu verkrijgbaar op dvd.}

De tiendelige serie (SF Studios, 2018) draait om advocaat Frank Nordling (Alexander Karim) en zijn geadopteerde zus Sara (Malin Buska). Na de moord op hun ouders groeit het duo gescheiden op in aparte pleeggezinnen. Sara maakt carrière als politieagent en blijft ondanks haar heroïneverslaving stug zoeken naar de moordenaar van haar ouders. Als er eenmaal een verdachte in beeld komt en die wordt vermoord, bemoeit ook Frank zich met de zaak. Hoewel de serie, gebaseerd op bestsellerreeks Easy Money van Jens Lapidus, niet heel origineel is, maken de duistere sfeer en het prima acteerwerk het toch de moeite waard om eens te kijken. Vanaf de bank krijgt de kijker genoeg intriges, spanning en blikken in de onderwereld voorgeschoteld. Via de Facebookpagina van het Advocatenblad (www.facebook.com/ advocatenblad) worden begin juni drie exemplaren van de dvd verloot.

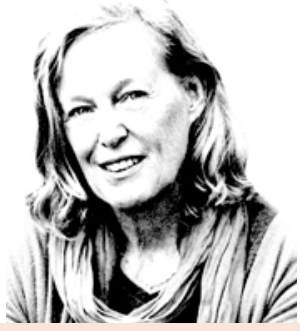

\title{
MR. X BELT, MAAR ER LUISTERT IEMAND MEE
}

Je mag als advocaat niet zomaar mensen laten mee luisteren met je telefoongesprekken. Alleen in dit geval mocht het wel.

M r. X zat in tuchtzaken. Haar cliënte was een radioloog tegen wie een klacht was ingediend. Mr. X nam de zaak over van een VvAA-jurist die door de radioloog al was afgeserveerd. Ook mr. X kon niet veel goed doen. Ze had volgens de cliënte twee keer het conceptverweerschrift enkele dagen later toegestuurd dan afgesproken. Dat concept zat dan ook nog eens vol spel- en taalfouten, onnauwkeurigheden en onnavolgbare wendingen. Bovendien had mr. X haar cliënte niet serieus genomen: 'Ik ben hier de jurist, u de dokter,' en 'als wij niet mijn manier van werken volgen, kunnen wij niet samenwerken.' Ten slotte had mr. X een derde laten meeluisteren als ze met haar cliënte belde, zonder haar daarvan op de hoogte te stellen. De radioloog was alweer overgestapt naar de volgende advocaat en diende tegen mr. X een klacht in.

Mr. X betwistte ongeveer alles, met uitzondering van het laten meeluisteren. Ze had de telefoon op de speaker gezet om aantekeningen te kunnen maken, maar dat was volgens haar geen punt - de extern ingehuurde 'kantoorgenoot-jurist' die het gesprek had kunnen horen, viel onder haar verantwoordelijkheid. De raad van discipline Arnhem-Leeuwarden acht alle bezwaren ongegrond, inclusief die over het laten meeluisteren. De meeluistereraar viel als kantoorgenoot-jurist onder verantwoordelijkheid van mr. X en had net als zij een geheimhoudingsplicht. $\mathrm{Nu}$ hij geen mededelingen mocht doen over wat hij had gehoord, had mr. X ook niet tuchtrechtelijk verwijtbaar gehandeld.

Huh? In gedragsregel 36 (van 1992) staat toch ongeclausuleerd dat je zonder toestemming niemand mag laten meeluisteren? In regel 4 van de herijkte regels vind je die bepaling in andere bewoordingen terug. En in 2017 was er nog een uitspraak waarin een klacht over per ongeluk onaangekondigd meeluisteren door een collega gegrond was, al zag het hof van discipline dat als zo'n kleine slordigheid dat het geen maatregel oplegde. Nergens iets over een uitzondering als de meeluisteraar geheimhoudingsplichtig is.

Het grote verschil is dat het in die zaak uit 2017 de wederpartij was die klaagde. Die heeft natuurlijk reden om bang te zijn dat hij op uitspraken in een tweegesprek door de aanwezigheid van een getuige wordt vastgepind. Een cliënt daarentegen zou zich normaal gesproken bij zijn eigen advocaat veilig moeten voelen en zou zich bovendien beschermd moeten weten door - inderdaad die geheimhoudingsplicht. Maar niemand vindt het echt prettig om tijdens of na een telefoongesprek te ontdekken dat er een derde in het spel is. (ECLI:NL: TADRARL:2018:87).

3 Op de website Advocatenblad.nl verschijnt elke woensdag een nieuwe tuchtrechtcolumn van Trudeke Sillevis Smitt. 